\title{
Using a Learning Styles Inventory to Examine Student Satisfaction with Web- Based Instruction: A 15-Year Study of One Professor's Web-Based Course Instruction
}

\author{
Ralph Olliges, PhD \\ Associate Professor, Department of Multidisciplinary Studies \\ Webster University
}

This article examines Active Engagement, Active Communication, and Peer Engagement learning practices among various student groups. It examines which tools are most important for increasing student satisfaction with web-based and web-enhanced instruction. Second, it looks at how different tools lead to greater satisfaction among different types of students (undergraduate, master's level, and doctoral level). Data were collected from 491 participants who answered an identical learning styles survey about technology-based pedagogical tools.

This study revealed that students enrolled in web-based courses taught by one professor demonstrate high levels of satisfaction in courses that provide active, engaging learning environments.

Teaching and its associated technologies have been evolving over the past 30 years. Many institutions offer online courses to expand options for their students. In order to accommodate them, as well as their various active learning styles, educators have moved from singular reliance upon the didactic lecture hall or a discussion seminar format to a full array of multimedia tools and techniques for communicating course content. The software that delivers the course content has changed as well. The overriding issue is not whether educators like these tools, but rather whether students' learning is enhanced. Part of the equation for improved learning is students' satisfaction with their learning experience using instructional courseware. All of the participants in this study were in classes that utilized web-based platforms such as WebCT, Blackboard, and Canvas. The focus of this study is to examine active learning styles and student satisfaction of undergraduate, master's level and doctoral students. However, first let us review the earlier work connected with this study.

\section{The Earlier Studies}

The initial work (Olliges, Wernet, \& Delicath, 1999; Wernet \& Olliges, 1999; Wernet, Olliges, \& Delicath, 2000a, 2000b) documented several findings concerning student satisfaction with electronically-based learning. Three concerns were identified as: access, exposure, and utility.

The studies in 2000 involved 1587 survey respondents. The participants in this study were lower division undergraduate students enrolled in freshman and sophomore level courses. These participants represented 39 courses across 26 different academic departments. The survey contained demographic information, course specific information, and a student learning style inventory. Some of the statements on the student learning style inventory were selected from the student inventory that Jerome E. Oberst of SUNY Oswego developed. Oberst's work was based on The Seven Principles for Good Practice in Undergraduate Education by Chickering and Gamson 
(1987). This work focused on improving undergraduate education and not on evaluating individual faculty.

Front-end access into course sites is a threshold for student satisfaction with web-based instruction. Like electricity, the network infrastructure is assumed to be constantly available. It should be a utility, not a commodity. This was not always the case in distance education prior to 2000. If a significant portion of the instruction time was spent addressing technical and Front-end access into course sites is a threshold network issues, then less time was spent on the actual for student satisfaction...

course content. Not having adequate access had a negative impact on students' feelings about technology-based instruction. If students are frustrated before they ever access the course material, their satisfaction level will be low.

The next concern was exposure. While most students are positive about online learning, they often express concerns over technical problems that they encounter during coursework (Gibbs, 1998). Technical problems included network downtimes, students learning how to effectively configure and operate their own computers, and the time commitment needed to download the material or to decode/encode the material.

The third concern was utility. The findings of the study revealed that students' satisfaction with web-enhanced courses is a function of involvement attributed to communication and course content as well as the type of student and the gender of the student. Nontraditional male students who feel involved are more satisfied than traditional female students who feel uninvolved (Olliges et al., 1999; Wernet \& Olliges, 1999; Wernet et al., 2000a, 2000b).

\section{The 15-Year Study}

In 2000, the decision was made to collect data using the same survey and follow one of the 39 instructors over the next 15 years (2001-2015) to see if these results would continue. This present study follows one instructor, in particular, the author of this paper. The instructor moved from a Midwest research university to a teaching university in the same city. Both were private institutions. The instructor taught undergraduate technology courses to primarily juniors and seniors, technology courses to graduate students, and a first year seminar which enrolled only traditionalage freshmen. Generally, first year seminars are taught by primarily full-time instructors on a topic that is of interest to them, but is not part of their discipline-based training.

Over time, the course software changed from Web Course Tools (WebCT) to BlackBoard to Canvas. However, the survey instrument remained constant over the 15-year period. It consisted of demographic information, course specific information, and a student learning style inventory. The learning style inventory dealt with how students interacted with their professor and their peers and how they sought assistance.

Although never perfect, access issues to computer networks during 2001-2015 continued to improve. Exposure to the internet kept growing because students saw a reason for using the internet. In particular, many graduate students preferred to take 
online classes because of the flexibility of time that these courses provided.

According to a Pew Research Report, adult internet usage in the United States rose from $50 \%$ to $84 \%$ from 2000 to 2015 . In addition, for some groups internet penetration is at full saturation. These groups include young adults, those with high levels of education, and those in more affluent households. Fifty-eight percent of senior citizens use the internet. In 2015, 78\% of blacks, $81 \%$ of Hispanics, $85 \%$ of Caucasians, and $97 \%$ of Asian-Americans (English-speaking) use the internet. Although rural dwellers are less likely than those living in urban areas to use the internet, still 78\% of rural residents are online (Perrin \& Duggan, 2015).

\section{Research Questions}

Fifteen years ago, the question that faced faculty and still does, is "Which tools are most important for increasing student satisfaction with web-based and webenhanced instruction?" A second question would be: Do different tools lead to greater satisfaction among different types of students (undergraduate, master's level, and doctoral level)? Clearly, communication tools are critical for learning and building learning communities in cyberspace (Palloff \& Pratt, 1999). However, it is not as clear which tools (and in what combination) are most useful in enhancing student satisfaction.

Kablan and Kaya (2014) found that "it can be concluded that teachers who prefer active learning methods tend to be better in implementing constructivist teaching methods and they might have adopted those strategies that are more aligned with their own learning style" (p. 73). Therefore, which tools are more important for increasing student satisfaction with web-enhanced instruction?

Lumpkin, Achen, and Dodd (2015a, 2015b) found that when technologynested instructional strategies are infused into classes, students perceive their learning as more engaging and enjoyable. Their study was limited to sport and health classrooms. The present study involves a wide range of disciplines such as educational technology, general education, and first year seminar students with various majors.

Whereas the previous study in 2000 looked at breadth (39 instructors), this longitudinal study focused on only one instructor. The purpose of the longitudinal study was to investigate how hybrid learning instruction affects students' learning outcome, satisfaction and sense of community by following one instructor over the past fifteen years.

"Many learning style models exist in literature, such as the learning style model by Kolb (1984), Honey and Mumford (1982), Pask (1976), and Felder and Silverman (1988). While there are still many open issues with respect to learning styles, the learning style models agree that learners have different ways in which they prefer to learn," according to Graf, Kinshuk, \& Liu (2009, p. 3).

This study builds on the earlier studies, but because this study spans 15 years and includes different populations, it can ask questions that were not explored previously. Because the same survey was used over a 15-year period, it is possible to study active learning styles and student satisfaction with three WebCT platforms and it is also possible to investigate differences among undergraduate, master's level, and doctoral level students. 
The author was interested in two questions. First, do the LMS software platform tools impact student satisfaction as a function of active learning and education level? Second, do undergraduate, master's level, and doctoral students have different learning styles, peer interactions, and expectations of their professors?

\section{Method}

This 15-year study is part of an ongoing tracking and assessment of webbased implementation by one instructor. These courses include both instructional technology (i.e., Curriculum/Instructional Design, Web Design, and computer literacy courses) as well as a first year seminar, non-technology related (i.e., an introductory course to an university general education program).

\section{Participants}

There were 460 survey respondents. The participants in this study were fairly evenly split between undergraduate (212) and graduate (248) students. Most of the graduate students were seeking a master's degree in educational technology; a few graduate students were studying at the doctoral level. Most (131) of the undergraduate students were enrolled in a computer literacy course with the remaining 81 enrolled in a first year seminar. There were 326 females (71\%) and 134 males (29\%) in the study. Most students were enrolled in traditional face-to-face courses using the LMS for webenhancement to submit assignments, to post discussions between class sessions, and to take exams. Often only one section of the course was offered. The format was mostly face-to-face.

Of the several demographic variables collected from students, three were used in the analysis: type of student, gender and technology course or non-technology course. The First Year Seminar classes were comprised of 18-19 year olds. The students in the undergraduate technology courses were anywhere from 18-40 years old. However, most undergraduate students were of traditional age. The graduate courses were mainly comprised of students aged 23 to 55, and overwhelmingly the majority were "non-traditional" working adults.

\section{Procedure}

The survey was conducted during the final weeks of each course. Rather than data collected online, data were collected using paper and pencil surveys so as not to bias the results of satisfaction with web-based education. Participation was voluntary and data were collected anonymously over a 15-year, five-terms per year period.

\section{Survey Instrument}

Students were asked about the course and their experiences with the technology used in the course (WebCT, Blackboard, Canvas) on a 5-point Likert-type scale ranging from 5 (very positive) to 1 (very negative). Students were also asked the degree to which they engaged in active learning while taking the course. These 14 items had good internal reliability (Cronbach Alpha $=.837$ ) and were derived from 
earlier work by the researcher. (See Olliges et al., 1999; Wernet \& Olliges, 1998 for a fuller discussion of the instrument and its validation).

\section{Results}

\section{Active Learning and Student Learning Styles Inventory and Factor Analysis}

Using 14 items, students were asked to report the degree to which they engaged in active learning while taking their course. A principal components analysis with varimax rotation was conducted on active learning items to determine how these items clustered. The results revealed that there were three factors underlying these variables. After rotation, the first factor (Active Engagement) accounted for $31.61 \%$ of the variance, the second factor (Active Communication) accounted for $15.71 \%$, and the third factor (Peer Engagement) accounted for 15.15\%. Table 1 displays the items and factor loadings for the rotated factors, with factor loadings less than .40 omitted to improve clarity.

Table 1

Active Learning Factor Analysis Item Loadings

Item

I am open to considering ideas that are different than mine.

My professor encourages dialogue in class.

My professor makes the course expectations clear at the beginning of the course. I assist other students when they ask for help.

I ask questions when I don't understand course material.

My professor encourages students to work together on coursework.

I discuss issues with students whose background \& .60 viewpoints differ from mine. I consciously adjust my learning style to the teaching of my professors.

.80

.76

\begin{tabular}{ccc} 
& Factor Loading \\
\hline Active & Active & Peer \\
Engagement & Communication & Engagement \\
\hline
\end{tabular}


Table 1 Continued

\begin{tabular}{|c|c|c|c|}
\hline & $\begin{array}{c}\text { Active } \\
\text { Engagement }\end{array}$ & $\begin{array}{c}\text { Active } \\
\text { Communication }\end{array}$ & $\begin{array}{c}\text { Peer } \\
\text { Engagement }\end{array}$ \\
\hline $\begin{array}{l}\text { I seek feedback from my } \\
\text { professors about my work. }\end{array}$ & .57 & .47 & \\
\hline $\begin{array}{l}\text { I correspond electronically } \\
\text { with my professors about my } \\
\text { courses. }\end{array}$ & & .79 & \\
\hline $\begin{array}{l}\text { I confer with my professor if I } \\
\text { am concerned about keeping } \\
\text { up with a particular class. }\end{array}$ & & .75 & \\
\hline $\begin{array}{l}\text { I correspond electronically } \\
\text { with my professors about } \\
\text { other stuff. }\end{array}$ & & .68 & \\
\hline $\begin{array}{l}\text { I work with other students in } \\
\text { informal groups. }\end{array}$ & & & .90 \\
\hline $\begin{array}{l}\text { I study with other students in } \\
\text { my course. }\end{array}$ & & & .90 \\
\hline Eigenvalues & 4.43 & 2.20 & 2.12 \\
\hline Percent of Variance & 31.61 & 15.71 & 15.15 \\
\hline
\end{tabular}

\section{Active Learning Difference between Student Populations}

A multivariate analysis of variance (MANOVA) was conducted to assess if there were differences between the different groups of students (undergraduate, masters, doctorate) on the Active Engagement dimension. A significant difference was found, Pillai's Trace $=.15, F(18,900)=4.12, p<.001$. Follow up univariate ANOVAs revealed significance among all of the variables which make up this dimension (see Table 2). In each case, doctoral students scored significantly higher than undergraduate students in their degree of Active Engagement. Masters students typically scored in between these two groups. A MANOVA was conducted to assess if student groups differed on the Active Communication dimension. Although means were in the expected direction, there were differences between groups, Wilks Lambda $=.98, F(6,910)=1.51, p=.17$. A MANOVA was also conducted to assess if groups differed on the Peer Engagement dimension. For each item, doctoral students scored significantly higher than masters and undergraduate students, Pillai's Trace $=.07, F(4$, $914)=8.17, p<.001$. 
Table 2

Means and (Standard Deviations) of Active Learning Differences between Student Populations

UG $\quad$ MA $\quad P h D \quad F$

Active Engagement

I am open to considering ideas that are

different than mine.

My professor encourages dialogue in class.

My professor makes the course expectations

clear at the beginning of the course.

I assist other students when they ask for help.

I ask questions when I don't understand course material.

My professor encourages students to work together on coursework.

I discuss issues with students whose

background \& viewpoints differ from mine.

I consciously adjust my learning style to the teaching of my professors.

I seek feedback from my professors about my work.

$\begin{array}{cccc}4.20 \mathrm{a} & 3.68 \mathrm{~b} & 4.52 \mathrm{c} & 19.91^{* * *} \\ (0.78) & (1.29) & (0.62) & \\ 3.87 \mathrm{a} & 3.54 \mathrm{~b} & 4.35 \mathrm{c} & 11.14^{* * *} \\ (0.99) & (1.31) & (0.77) & \\ 4.25 \mathrm{a} & 3.66 \mathrm{~b} & 4.30 \mathrm{a} & 16.16^{* * *} \\ (0.87) & (1.37) & (0.76) & \\ 3.98 \mathrm{a} & 3.56 \mathrm{~b} & 4.26 \mathrm{a} & 13.56^{* * *} \\ (0.93) & (1.16) & (0.68) & \\ 4.13 \mathrm{a} & 3.65 \mathrm{~b} & 4.26 \mathrm{a} & 14.83^{* * *} \\ (0.86) & (1.16) & (0.71) & \\ 3.40 \mathrm{a} & 3.23 \mathrm{a} & 4.02 \mathrm{~b} & 10.50^{* * *} \\ (1.00) & (1.16) & (0.86) & \\ 3.76 \mathrm{a} & 3.39 \mathrm{~b} & 4.17 \mathrm{c} & 15.54^{* * *} \\ (0.91) & (1.05) & (0.77) & \\ 3.63 \mathrm{a} & 3.32 \mathrm{~b} & 3.89 \mathrm{a} & 8.14^{* * *} \\ (1.02) & (1.07) & (0.80) & \\ 3.78 \mathrm{a} & 3.52 \mathrm{~b} & 4.22 \mathrm{c} & 8.61^{* * *} \\ (1.07) & (1.16) & (0.66) & \end{array}$

Active Communication

\begin{tabular}{lcccc} 
I correspond electronically with my & 3.40 & 3.19 & 3.50 & \multirow{2}{*}{3.14} \\
professors about my courses. & $(0.99)$ & $(1.02)$ & $(0.94)$ & \\
I confer with my professor if I am & 3.46 & 3.28 & 3.59 & \\
$\begin{array}{l}\text { concerned about keeping up with a } \\
\text { particular class. }\end{array}$ & $(1.16)$ & $(1.14)$ & $(1.00)$ & 1.98 \\
$\begin{array}{l}\text { I correspond electronically with my } \\
\text { professors about other stuff. }\end{array}$ & 2.86 & 2.85 & 2.76 & 0.12 \\
& $(1.26)$ & $(1.28)$ & $(1.30)$ & \\
Peer Engagement & & & & \\
\hline I work with other students in informal & $2.79 \mathrm{a}$ & $2.84 \mathrm{a}$ & $3.63 \mathrm{~b}$ & \multirow{2}{*}{$9.52^{* * *}$} \\
groups. & $(1.18)$ & $(1.29)$ & $(0.93)$ & \\
I study with other students in my course. & $2.66 \mathrm{a}$ & $2.71 \mathrm{a}$ & $3.83 \mathrm{~b}$ & $16.93^{* * *}$ \\
& $(1.22)$ & $(1.39)$ & $(0.90)$ & \\
\hline
\end{tabular}

Note. ${ }^{*} p<.05 ;{ }^{* *} p<.01,{ }^{* * *} p<.001$ significance. All $F$-ratios had 2 and 457 as their degrees of freedom. Means and standard deviations with shared superscripts are not significantly different according to Games-Howell post-hoc analyses. 


\section{Online Course Tools vs. Course Assessments as a Function of Active Learning}

Over the past 15 years, the stimulus materials have been given to 212 undergraduates, 202 master's level, and 46 doctoral level students. An ANOVA was conducted to examine if there were any differences in course satisfaction between the three groups of students. The results revealed that student satisfaction differed between students, $F(2,457)=9.50, p<.001$. A Games-Howell post-hoc analysis revealed that doctoral level students $(M=4.30, S D=0.81)$ and master's level students $(M=3.63$, $S D=1.38$ ) reported a significantly better experience with the online platform than undergraduate students $(M=3.41, S D=1.25)$. There was no difference between PhD and master's students. Interestingly, when participants were asked if they would like to sign up for another online class, $97 \%$ of undergraduates and $100 \%$ of doctoral students were either supportive or indifferent to taking another online course. On the other hand, $17 \%$ of master's students were opposed to taking another online course, $\mathrm{X}^{2}$ $(4, N=460)=50.88, p<.001$.

A series of analyses were conducted to examine how active learners felt about the online environment. The 14 active learning items were summed and split into the upper and lower quartile. Students who were high in active learning $(N=107)$ were compared to those students who were low on this dimension $(N=107)$ to determine if there were any differences in online course satisfaction, $t(210.22)=-5.96, p<.001$. Those students who were high in active learning reported being statistically more satisfied with the course $(M=3.96, S D=1.21)$ than those students low in active learning $(M=$ $2.93, S D=1.33)$. In addition, when participants were asked if they would like to sign up for another online class, $26 \%$ of students who were low in active learning were opposed to taking another online course. None of the students high in active learning expressed a desire to avoid online courses in the future, $X^{2}=32.22, d f=2, N=214$, $p<.001$.

According to a MANOVA, students who were high in active learning were significantly more likely to rate online course tools (e.g., syllabus, calendar, gradebook, email) as having positively impacted their course involvement [Pillai's Trace $=.37, F(4$, $205)=29.87, p<.001$.] and grade [Pillai's Trace $=.38, F(4,202)=30.62, p<.001$.] than those students low in active learning (see Table 3). Similarly, MANOVA results revealed that students high in active learning were significantly more likely to rate online course assessments as positively impacting their course involvement [Pillai's Trace $=.35, F(6$, $199)=17.56, p<.001$.] and grade [Pillai's Trace $=.38, F(6,198)=19.88, p<.001$.] than those students low in active learning (see Table 3). 
Table 3

Differences in the Impact of Online Course Tools and Course Assessments as a Function of Active Learning (AL)

\begin{tabular}{|c|c|c|c|c|c|c|}
\hline \multirow{4}{*}{ Online Course Tools } & \multicolumn{3}{|c|}{ Course Involvement } & \multicolumn{3}{|c|}{ Course Grade } \\
\hline & \multicolumn{2}{|c|}{$M(S D)$} & \multirow[t]{3}{*}{$F$} & \multicolumn{2}{|c|}{$M(S D)$} & \multirow[t]{3}{*}{$F$} \\
\hline & High & Low & & High & Low & \\
\hline & $\mathrm{AL}$ & $\mathrm{AL}$ & & AL & $\mathrm{AL}$ & \\
\hline \multirow{2}{*}{ Course Syllabus } & 3.83 & 2.53 & \multirow{2}{*}{97.27} & 3.78 & 2.49 & \multirow[t]{2}{*}{104.57} \\
\hline & $(0.45)$ & $(1.27)$ & & $(0.44)$ & $(1.20)$ & \\
\hline Course & 3.36 & 2.45 & \multirow{2}{*}{33.71} & 3.29 & 2.45 & \multirow[t]{2}{*}{34.44} \\
\hline Calendar & $(0.97)$ & $(1.27)$ & & $(0.87)$ & $(1.17)$ & \\
\hline Online & 3.93 & 2.66 & \multirow{2}{*}{83.26} & 3.87 & 2.60 & \multirow[t]{2}{*}{86.41} \\
\hline Gradebook & $(0.35)$ & $(1.38)$ & & $(0.48)$ & $(1.31)$ & \\
\hline \multirow{2}{*}{ Platform Email } & 3.75 & 2.46 & \multirow{2}{*}{76.13} & 3.62 & 2.40 & \multirow[t]{2}{*}{73.73} \\
\hline & $(0.65)$ & $(1.36)$ & & $(0.70)$ & $(1.26)$ & \\
\hline \multirow{2}{*}{\multicolumn{7}{|c|}{$\begin{array}{l}\text { Online Course } \\
\text { Assessments }\end{array}$}} \\
\hline & & & & & & \\
\hline Online & 3.79 & 2.74 & 53.84 & 3.74 & 2.69 & 55.30 \\
\hline Quizzes/Tests & $(0.60)$ & $(1.32)$ & & $(0.58)$ & $(1.30)$ & \\
\hline \multirow{2}{*}{ Hyperlinks } & 3.63 & 2.39 & \multirow[t]{2}{*}{64.25} & 3.49 & 2.44 & \multirow[t]{2}{*}{46.19} \\
\hline & $(0.81)$ & $(1.33)$ & & $(0.86)$ & $(1.29)$ & \\
\hline Online & 3.76 & 2.46 & \multirow[t]{2}{*}{71.30} & 3.81 & 2.40 & \multirow[t]{2}{*}{90.26} \\
\hline Notes/Lectures & $(0.69)$ & $(1.40)$ & & $(0.54)$ & $(1.39)$ & \\
\hline Online & 3.98 & 2.74 & \multirow[t]{2}{*}{77.68} & 3.97 & 2.64 & \multirow[t]{2}{*}{88.47} \\
\hline Assignments & $(0.14)$ & $(1.41)$ & & $(0.17)$ & $(1.41)$ & \\
\hline \multirow{2}{*}{ Chat Room } & 2.38 & 2.30 & 0.22 & 2.49 & 2.31 & 1.03, \\
\hline & $(1.31)$ & $(1.29)$ & $p=.64$ & $(1.21)$ & $(1.29)$ & $p=.31$ \\
\hline \multirow{2}{*}{ Bulletin Board } & 3.44 & 2.34 & 50.00 & 3.40 & 2.39 & 41.26 \\
\hline & $(0.93)$ & $(1.28)$ & & $(0.92)$ & $(1.28)$ & \\
\hline
\end{tabular}

Note. Reported F-ratio values were statistically significant at $p<.001$, but when they were not the $p$-value was provided.

\section{Discussion}

\section{Interpretation of Findings}

Several important findings emerge from the present study. The same 14-item learning style inventory that was used with 1587 lower-level undergraduate students at the turn of the century in 1999 and 2000 proved to be a valuable survey instrument for 15 years and appropriate for use with both undergraduate and graduate students. During this 15-year period, internet use rapidly increased and many new educational technologies emerged. And yet, the survey continued to demonstrate the importance of active learning and student engagement in web-based and web-enhanced courses. 
Table 1 for the active learning factor analysis item loadings has three factors: Active Engagement, Active Communication, and Peer Engagement. An example of an active engagement tool is clickers or a website such as poll everywhere (https://www.pollev.com) where students provide immediate feedback to the instructor during a class session. Active communication refers to providing students a timely response within 24 hours to their questions or text messages. A peer engagement example is creating team projects where students need to work together to solve issues. It could include students arguing opposite viewpoints on a particular topic. It might include a team project where they need to take a photo of their team mates in front of various campus buildings.

The key to satisfaction is involving the students in the course. Online courses need to go beyond the text-heavy material with minimal interaction. As was found previously, the online courses need multimedia presentations which simulate the classroom experience, interactive communication opportunities that incorporate feedback loops and student interaction, and electronic testing (Navarro \& Shoemaker,

...the online courses need multimedia presentations which simulate the classroom experience...
1999; Olliges et al., 1999). Unlike traditional classrooms, mediated communication through tools and course content, which replace face-to-face interaction, are crucial to enhancing student satisfaction. These tools and content must consciously hook and engage students. Engagement equates to interaction that equates to involvement. If students' feel involved through communication and through course content, they will be satisfied. Therefore, faculty need to take special care in their design of course content and the means by which it communicates with students in web-enhanced and webbased courses.

Another finding focuses upon cooperation among students. The students need opportunity to work with others who have different points of view. Prompt feedback is important for all three groups. Lumpkin and others (2015a, 2015b) found that when technology-nested instructional strategies are infused into classes, students perceive their learning as more engaging and enjoyable. Their study was limited to sport and health classrooms. The present study involves a wide range of disciplines such as educational technology, general education, and first year seminar students with various majors. The present study supported the original findings of Lumpkin and colleagues.

\section{Limitations}

One obvious limitation is that this 15-year study followed one professor. It is possible that results might differ following other professors. However, this limitation could be considered a strength of this study. Lumpkin et al. (2015) encourage faculty to "conduct action research in their courses so they can discover more about how students perceive their learning" (p. 132). Helpful in this process would be the development of valid and reliable assessments of student perceptions to connect learning outcomes to specific active learning strategies used. The present study has already accomplished what the authors called for in 2015. The present study uses a 
"valid and reliable" instrument that discovers "how students perceive their learning." The present study demonstrates that active engagement, active communication, and peer engagement are tied to student satisfaction in web-based and web-enhanced courses.

\section{Future Studies}

This paper used data collected to examine the effect of one demographic (undergraduates, master's and doctoral students) on student satisfaction. Several questions evolve from these findings. A deeper examination of the data needs to take place. The means for the undergraduates and doctoral students were higher than for the master's students. Does this imply that doctoral and undergraduate students have a higher curiosity and openness to learning or different motivations for learning than master's students? The implications of the findings should be studied more. Future research will examine the relationship of the demographics on student satisfaction.

\section{Acknowledgments}

I owe a great deal of gratitude to two colleagues, Stephen Wernet and Tim Delicath, who started me down the path of researching learning styles and technology. I would like to thank Mike Hulsizer for his help with the statistics and Debbie Stiles for her suggestions in the paper.

\section{References}

Chickering, A. W., \& Gamson, Z. F. (1987). Seven principles for good practice in undergraduate education. American Association for Higher Education Bulletin, 39, 3-7. Retrieved from https://www.aahea.org/index.php/aaheabulletin

Gibbs, W. (1998). Implementing on-line learning environments. Journal of Computing in Higher Education, 10(1), 3-28. doi: 10.1007/BF02946984

Graf, S., Kinshuk, \& Liu, T. (2009). Supporting teachers in identifying students' learning styles in learning management systems: An automatic student modelling approach [Special issue]. Educational Technology E Society, 12(4), 3-14. Retrieved from http://www.ifets.info/index.php
Kablan, Z., \& Kaya, S. (2014). Pre-service teachers' constructivist teaching scores based on their learning styles. Australian Journal of Teacher Education, 39(12). doi: 10.14221/ajte.2014v39n12.5

Lumpkin, A. L., Achen, R. M., \& Dodd, R. K. (2015a). Student perceptions of active learning. College Student Journal, 49(1), 121-133. Retrieved from http://www.projectinnovation.com/colleg e-student-journal.html

Lumpkin, A. L., Achen, R. M., \& Dodd, R. K. (2015b). Using technology-nested strategies to enhance student learning. InSight: A Journal of Scholarly Teaching, 10, 114-125. Retrieved from http://insightjournal.net/ 
Navarro, P., \& Shoemaker, J. (1999). The power of cyberlearning: An empirical test. Journal of Computing in Higher Education, 11(1), 29-54. doi: 10.1007/BF02940841

Olliges, R. H., Wernet, S. P., \& Delicath, T. A. (1999). Using WebCT for educating practice professionals. Electronic Conference Proceedings of the Dancing Web Conference. TELR, Ohio State University, ColumbusH.

Palloff, R., \& Pratt, K. (1999). Building learning communities in cyberspace. Effective strategies for the online classroom. San Francisco, CA: Jossey-Bass Publishers.

Perrin, A., \& Duggan, M. (2015). Americans' internet access: 2000-2015: As internet use nears saturation for some groups, a look at patterns of adoption. Pew Research Center. Retrieved from http://www.pewinternet.org/2015/06/26/a mericans-internet-access-2000-2015/

Wernet, S. P., \& Olliges, R. H. (1998). The application of WebCT (Web course tools) in social work education. Conference Program and Proceedings. Information Technologies for Social Work Education and Practice. College of Social Work, University of South Carolina, Columbia.
Wernet, S. P., \& Olliges, R. H. (1999).

Using WebCT for educating practice professionals. Proceedings of the First Annual WebCT Conference on Learning Teachnologies: From Innovation to Implementation. WebCT'99. The University of British Columbia, Vancouver.

Wernet, S. P., Olliges, R. H. \& Delicath, T. A. (2000a). Post-course evaluations of WebCT (Web course tools) classes by social work students. Research in Social Work Practice, 10, 487-504. Retrieved from http://journals.sagepub.com/home/rsw

Wernet, S. P., Olliges, R. H., \& Delicath, T. A. (2000b). What works, what doesn't: Modeling instructional tools to enhance student satisfaction with web-based instruction. WebCT Conference on Learning Technologies 2nd Annual Proceedings. Athens, Georgia.

Ralph H. Olliges is Associate Professor of Education at Webster University in Saint Louis. Also, he is the Educational Technology Coordinator with over 100 students in the master's level program. He coordinates the Master's of Educational Technology (MET), the Certificate in Online Teaching and Learning, and the EdS in Technology Leadership. Dr. Olliges possesses over thirty-three years of teaching experience in the classroom and online. His area of expertise deals with how to successfully integrate technology in the classroom. He has numerous publications and presentations with regards to using technology in the classroom and with student learning styles. 